\title{
A Proposal System Design of Evaluating Employees Performance in Qaladze Bank, Kurdistan Region of Iraq
}

\section{Muzhgan Ibrahim Hassan}

Department of Administration And Financial, Raparin Directorate of Investment, Board of Investment,Erbil, Kurdistan Region, Iraq.

E-mail: ebrahim.mozhgan@gmail.com

\section{Aso Kurdo Ahmed}

Department of Business Management, College of Business and Economic, Lebanese France University, Erbil, Kurdistan Region, Iraq.

E-mail: Aso.Ahmed@1fu.edu.krd

\begin{abstract}
:
This study presents a new model for Evaluating employees' performance by considering their job criteria so that employees are evaluated not only on the basis of their individual criteria but also on the job criteria they are working on. This is the most important feature of this research compared to previous cases. Based on the presented model, the relevant criteria with discrete coefficients are determined for the two individual criteria and job criteria. Individual criteria were obtained through library studies and partial selection into three managerial, social, and technical groups. Occupational criteria were selected based on the results of one of the studies. To determine the coefficients of the principal and subindividual criteria, the simple and fuzzy AHP method is used to determine occupational criteria, respectively, and the simple and fuzzy AHP paired scales To determine the coefficients of job criteria. Finally, each employee is given scores (maximum 5) on each of the occupational and individual criteria. Employee rankings are based on the coefficients of individual and occupational criteria as well as the points earned, using TOPSIS algorithm. The final score of each employee is calculated based on the average score of two points obtained by the TOPSIS method. All of the above steps are designed in the TOPSIS format of an Excel spreadsheet decision support system with VB programming language and at Qaladze Bank level, which consists of 75 employees and 10 departments. In order to execute the model more accurately, it is recommended that a person or group be consulted on all the jobs of the organization to comment on all the coefficients of the available jobs in the organization to make assertions about the business coefficients that underlie the proposed model. Also add a 360-degree evaluation method to measure people from different perspectives.
\end{abstract}

Keywords: Performance Evaluation, Multi-Criteria Decision Making Models, Job Criteria, Decision Support System. 


\section{Introduction:}

Employees are the most important asset of an organization. Features and resources such as organization strategy, business models, services and products can be copied from competing companies. However, employees are the only thing that really shapes the organization (Bazar Jazayeri, 2008).

Because improvement in any organization requires measuring employee performance, planning and goal setting to improve their performance, obviously everyone knows the importance of the need to measure individual performance. But despite significant advances in the design of performance appraisal frameworks, models, and systems in recent years, many organizations still rely on traditional criteria. One of the reasons for this problem is the new models in this field express only conceptual and fundamental issues and rarely they are operational. Therefore, how to apply this operational framework in a particular organization to create a unique performance appraisal system is based on the needs of the organization which is a subject that requires more work (Karimi, 2007).

Qaladze Bank, which started operating on January 22 / 2007 in the city of Qaladze, Sulaymaniyah, Iraq, is considered as a case study in this paper to implement the proposed model in this article. Although many frameworks and methodologies have been introduced in the field of evaluating employee's performance, each of them is focusing on a different aspect of performance and being unique and all have a generality of claims, but each has its weaknesses. One of the things that seem to be overlooked in evaluating employees' performance is the type and nature of the job he is working on. Every person needs to have the skills to fit into a job, but each job has its own set of features that make it unique and people need to have the skills to do it. This paper attempts to present a model in the form of a decision support system to recall one of the hidden aspects of one's performance appraisal, but first two examples of worldwide studies are discussed below:

First): Employee performance appraisal was performed in 360 degrees using Multiple Attribute Decision Making (MADM) models. In this paper, performance appraisal is seen as an element of the decision-making team and therefore a 360-degree performance appraisal model is used in which employees are evaluated from different perspectives (boss, co-worker, assistant, employee, customer, etc.). .

In this study, which evaluates the performance of the middle managers of the organization, each manager is evaluated by 4 evaluators (1.Manager evaluation, 2.Coworkers evaluation, 3.Assistants evaluation, 4.Individual self-evaluation). Options A1, A2, A3, A4, A5 were assigned to the managers and the evaluation criteria after sorting through different MADM methods are as follows: Based on TOPSIS method (A A3 > A1 > A4 > A2 >> A5, based on Borda A3 > A1 > A4 > A2 > A5, A2 > A4 > A1 > A3 > A5 and Electra A3 > A1 A2 > A4 A5 (Moon et al. 2007: 661).

Second): The design of a decision support system for performance appraisal by Dr. Dominic et al. In the public sector, the Welding Industry Production Organization was done in 2008. The essential purpose of the research is to estimate the performance of individuals in each part of the organization and finally arrange the sections and determine the individual scores based on the performance of each department using the decision support system. Information on indicators for employee evaluation is collected through a questionnaire and interviewed on an individual basis. This organization has a department. In this paper, the researcher proposes a weighted mathematical model to calculate 4 points for each employee, which is the sum of the weighted-technical, individual and social management scores. 
One of the problems of this model is the difficulty of allocating weight for each social, managerial and personal attribute. However, weights can be assigned by the decision maker based on the nature of each sector and the experience of the decision maker (P.D.D.Dominic et al., 2008).

As can be seen, the decision-making techniques used in performance appraisal include multi-criteria decision-making techniques. There are two major categories of different approaches to information processing in a multi-criteria decisionmaking problem in the literature:

One set of methods derives from one model known as the non-compensatory model and the other one derives from another model known as the compensatory model.

1. Compensation model: It involves methods in which exchange between indices is not permitted; this means that the disadvantage of one index is not compensated by the advantage of the other index. Therefore, each index in these methods alone is indexed by index-to-index comparisons (Asgharpour, 2008).

2. Compensation model: It involves methods in which permissions are allowed to be exchanged between indices, ie a (possibly small) change in one index can be offset by an opposite change in another index (or indices) (Asgharpour, 2008).

\section{Applications:}

Performance measurement information is widely used for service compensation, performance improvement, and documentation. It can also be used in personnel related decisions (such as promotion, transfer, dismissal); training needs analysis, staff development, research and program evaluation. Performance management systems, which are directly linked to the organization's reward system, provide a strong incentive for employees to pursue organizational goals yearon-year and creatively. As long as the performance management system is properly designed and implemented, it doesn't only allow only allows employees to know the quality of the current performance of the badge, but also clarifies the actions they need to take to improve their performance.

\section{Advantages:}

Communication Facilitation: Continuous discussion and feedback of employees with managers, on the other hand, motivates employees and gives managers more insight.

Increasing Focus on Employees by Increasing Mutual Trust: Building mutual agreement and enhancing mutual trust increases employee accountability and increases managers' focus.

Setting goals and enhancing desired performance: By defining and agreeing on individual goals and adapting them to organizational goals, the focus on individual and organizational performance in a mutually satisfying process is enhanced.

Performance Improvement: By establishing a performance appraisal system, employees' perceptions of their organizational expectations are enhanced and by creating a positive interaction between queue units and HR units, improving the performance of the individual and the organization. 
Determining Educational Needs: One of the important outcomes of performance evaluation is identifying the areas needed for the development of individuals that can determine their educational needs.

\section{Disadvantages:}

Quality Improvement Disruption: The use of performance evaluation systems has a negative impact on organizations that use a comprehensive quality management system. Subjective evaluations instead of objective: Some managers use subjective evaluations that are free of personal interests and prejudices and other mistakes rather than relying on objective evaluations based on predetermined goals. (Asqharpour, 2008)

Negative Views on Performance Evaluation: There may be some negative views on performance evaluation in the organization. Managers generally see it as an over-the-top process that creates potential tensions between themselves and employees, and employees often lack confidence in the evaluator and believe that evaluators do not include the correct information in the evaluation forms.(Asqharpour, 2008)

Appraisal Errors: Appraisal errors, which are predominantly present in judgment evaluations, are also a threat to the accuracy of performance appraisals.

Troubleshooting Legal Issues in the Organization: If a performance evaluation is not performed well in the organization, it can involve the organization in some internal legal problems including disruption to disciplinary programs, promotional decisions, and external problems, including employee legal action against the organization. Overemphasis on Performance Goals: Overemphasis on achieving performance goals sometimes can lead one to ignore or challenge ethics, legal requirements, or quality in the organization and impeding the knowledge and skills and training required of employees.

Problems with pay and rewards: In researcher's opinion, grounding researchers believe that directly linking the payroll system to the performance appraisal system will impair performance, quality and effectiveness of the appraisal, and leads employees to look good.

\section{Approaches to performance evaluation:}

Performance management systems "To manage and align" all the resources of the organization are used to achieve the highest level of performance. "How the performance that is managed in an organization largely determines its success or failure. Therefore, improving the performance appraisal for each individual should be in line with the organization's current priorities. "Performance appraisal approaches and approaches to properly evaluate performance, we should identify and evaluate performance appraisal approaches and practices in specific situations. In general, five approaches to performance evaluation have been introduced. These are included:

1. Comparative approach: A comparative approach to performance management requires the evaluator compare the performance of others with others. This approach typically uses a comprehensive evaluation of an individual's or value's performance to rank the individuals in a workgroup. At least three techniques are used in this approach, including: ranking, forced distribution, and pairwise comparison. 
2. Individual attributes approach: This approach to performance management emphasizes the development of certain attributes that are considered desirable for the success of the organization. The techniques used in this approach include a set of behaviors and traits, including: initiative, leadership, competitive character, and individual evaluation.

3. Behavioral approach: This approach attempts to define the behaviors that an employee should perform in order to be effective in his or her work. A variety of techniques are defined in this approach that requires an employee to evaluate which employee exhibits these behaviors. These techniques include 5 techniques: sensitive events, behavioral rating scales, behavioral observation scales, organizational behavior modification, and measurement centers.

4. Outcome approach: This approach focuses on goal management, measurable outcomes of a job, and workgroups. This approach assumes that one can separate one's personality from the measurement process. In this case the results are the closest indicators of individual characteristics to organizational effectiveness. The two performance management systems that fall under this approach include: goal-based management and a system of productivity evaluation and measurement.

5. Quality approach: The four approaches mentioned traditional approaches to measure and evaluate the employees' performance are considered. The two main features of the quality-customer orientation and error prevention approach are: improving the satisfaction of internal and external customers is one of the primary goals of the quality approach. Performance Evaluation Methods there are various methods for evaluating employee performance that can be categorized into any of the approaches which mentioned, but which one is the most appropriate or the best evaluation method is depending on the organization's purpose of staff evaluation and usually a combination of different methods are used to evaluate the employees.

Referring to key factors in the effectiveness of performance appraisal systems, some of the characteristics of effective performance appraisal systems include:

1. Effort for greater accuracy in defining and measuring performance dimensions as far as possible.

- Define performance by focusing on the evaluated outcomes

- Outcome predictions in terms of frequency and frequency of related behavior.

- Define the dimensions of performance by combining tasks with different aspects of value (such as quality, quantity, suitability and appropriateness)

2- Connecting the dimensions of performance to meet the needs of internal and external customers

3. Combining and integrating measurement of situational constraints, focusing attention on the observed constraints on performance

4. Enough trust between supervisors and subordinates.

5. Measuring and guiding the performance of employees in general and tangible

6- There is some kind of fitting between the organization's culture and its evaluation policies

7. Supervisors are interested in explaining the evaluation system to staff and discussing how it is implemented. 
8. Evaluation encourages professional growth performance and facilitates the transfer of its culture.

9. Staff has the opportunity to comment on issues and discuss goals and plans.

10. Employees receive consistent and consistent feedback from a variety of sources in order to gain the necessary knowledge of their position in relation to expect performance.

11. Self-assessment is part of the formal feedback process.

12. Increase payments are based on both individual performance and group performance.

As aforementioned, performance appraisal is done for a variety of purposes, such as career development, accountability control, and as a mechanism for determining employee pay increases and remuneration. In general, it needs a tool that can improve decision-making regarding performance appraisal. Many efforts have been made to develop appropriate software tools that can be used as a management consultant. Essential in the decision-making process of evaluating a firm's performance. Decision support systems are a specific group of computer information systems that support business and organizational decision - making activities.

An appropriately designed decision support system is a software-based system intended to assist decision makers by collecting useful information from data, organizational knowledge documents, or business models to identify problems and make decisions (Asqharpour, 2008).

In another study; first, a study was conducted to summarize the opinions of employees' disinterest in performance appraisal and then, from the perspective of performance appraisal itself, the study explored the reasons why employees were reluctant to do so. Employee performance appraisal has been discussed, which consists of three parts: direct performance factors, indirect performance factors, and performance score analysis. (Y-J. Wu \& J-L. Hou, 2010) According to another study, performance rating and evaluation have been mentioned. Systematically nominating people to advance in human resource management is a strategic thing. In this research, an approach is proposed to promote these individuals using fuzzy theory and electronic nomenclature technique (Moon et al.,010, p.512).

In another study, it assessed the performance of the R\&D staff in the organization. This study considers criteria such as hardiness, ability, and morale for employees, and uses the AHP method to determine the weight of the indicators. In another research, considering uncertainty has been used ( Espinilla et al., 2013, p. 459-471).

In this research, it is attempted to present a model that considers the work in evaluating the performance of employees and to use a multi-attribute decision-making approach to develop a decision support system for the organization under study. We examine the logic of the proposed model and the software developed for it, and in the third section we describe the functional details of the model and explain how to derive the criteria used in the model. In the fourth section we discuss the details of the model implementation and in the fifth section we present the results and suggestions. 


\section{Designing an Employee Performance Evaluation Model for the Qaladze Bank:}

As aforementioned bank performance appraisal, it can be seen that the employees of different departments complained of the outcome of the appraisal and stated that: (Are employees in jobs that are completely different in nature? Can it be compared to the same forms that contain the same criteria and the same coefficients?) (Isn't sensitivity, complexity, workload, financial consequences and other characteristics of jobs different?) The mentioned problem on the one hand and the problem with doing the appraisal on the other hand, when the evaluation criteria for different departments are different, on the other hand, implementation of the performance appraisal system is difficult.

Pointing out that, employees in different departments must have different abilities, for example financial sector employees must be very careful, R\&D (Research \& Development) staff, creativity and innovation, and public relations department staff need extensive communication. On the other hand, each job has its own characteristics, so it seems that each employee should have two characteristics:

1) Individual attributes that is included the attributes that one must possess in the job.

2) Job characteristics that are due to the different nature of the jobs relative to each other. But in spite of the similarity of individual and occupational characteristics for all employees, in order to show the differences which were shown above, this difference should be calculated according to the criteria required. Figure 4 shows the proposed model of this study, based on which occupational criteria and one is measured in one's performance evaluation.

As can be seen, this model consists of two types of criteria: Individual and Occupational Criteria. Individual criteria state that each individual in each job must have the criteria that the job requires. The individual criteria expres sed in this model include two criteria. This category means that people with managerial jobs need to have higher managerial coefficients; bachelor jobs receive higher technical coefficients, and executives with higher coefficients.

For this reason, the comparative matrix of the core groups on the one hand and the comparative matrix of individual criteria (including social, technical and managerial) are expressed on the other hand. Job descriptions state that each job has characteristics that are specific to the job. These attributes are also applied to all jobs and the difference in jobs is determined by the coefficients of the criteria.

Figure (1): Proposed Model for Evaluating Staff Performance (Jalaian \& seifbarqy, 20143)

\section{Extraction of occupational and individual criteria:}

As noted earlier, in order to extract appropriate occupational and individual criteria, after studying internal and external sources, on individual criteria, 38 criteria were divided into three subgroups of managerial, social, and technical criteria, and 11 on occupational criteria. The four subgroups of skill, responsibility, effort and working conditions were extracted and for validation, the individual criteria in the questionnaire were given to a number of experts in the organization using 15 individual criteria (statistical test method). For each of the three groups, 5 criteria) and 11 occupational criteria as performance evaluation criteria, approved. 


\section{Steps to establish and validate individual criteria:}

\section{Extract 38 suggested criteria from the sources studied.}

2. Provide a questionnaire and submit it to the managers of the organization to validate the criteria. (The study assumes that high-level managers of the organization, including managers and heads of independent departments, are experts in the organization because of their surroundings in the organization, and therefore their views have been used to validate the criteria.)

3. In this regard, 11 questionnaires were submitted to the manager of the organization, and one questionnaire was not returned.

4. Questionnaires and Criteria (since only five criteria were considered for each core group (social, technical and managerial), 15 criteria were extracted based on managers' views and using statistical tests). :

Social Criteria: Work Conscience, Polite Behavior, Employee Fitness, Employee Commitment and Responsibility, Regular Discipline and Confidence.

Technical Criteria: Tracking issues, perseverance and seriousness at work, work experience, mastery of work and subject knowledge, productivity.

Management Criteria: Focus on Goals, Planning Ability, Communication, Innovation and Creativity.

\section{Procedures for determining and approving occupational criteria:}

Noting that job criteria are specifically collected in several sources (Ronaq, 2007) and (Sa'adat, 2007) and given their comprehensiveness, they are fully utilized in this research and are assumed to be in the absence of specific features in a job, assign a minimum score for that feature. Therefore, the four occupational criteria used in this study are as follows:

Skills: Education and Experience;

Responsibility: Supervision, safety of others, materials and products, contact and communication with others, finances, forms and reports.

Effort: Physical effort and mental effort.

Working Conditions: Unfavorable work environment/ occupational hazards and illness.

\section{Individual criteria coefficients:}

In order to derive the individual criteria coefficients from the pairwise comparisons in the simple AHP method (to determine the coefficients of the main features, namely social, managerial, and technical features) and the fuzzy AHP (to determine the coefficients of each of the social, managerial, and technical criteria) It has been used to ask managers in each department to apply their preferences according to their jobs in their respective paired comparator matrices. The following table shows the pairwise scale matrix of the coefficients of the main demographic characteristics of the organization as an example. 
Table (1): Couple Scale Matrix of Properties (Principal Criteria)

\begin{tabular}{c|c|c|c|}
\hline Social features & Management features & \multicolumn{1}{c}{ TECHNICAL FEATURES } & \\
\hline $\mathbf{1}$ & 2 & 2 & Social features \\
\hline $\mathbf{0 . 5}$ & 1 & 2 & Management features \\
\hline $\mathbf{0 . 5}$ & 0.5 & 1 & TECHNICAL FEATURES \\
\hline
\end{tabular}

After receiving managers' opinions on preferences in different occupations, incompatibility is assessed. Complete implementation of the proposed model, including weighting of the main and sub-features (criteria), is presented in the decision support system in Section Four.

\section{Job Criteria Coefficients:}

In order to extract job coefficients, paired comparisons were used in a simple AHP method. To this end, managers in each department were asked to complete occupational preference forms regarding their occupations. After receiving preferences from managers, incompatibility coefficients are also calculated.

\section{Individual criteria coefficients:}

Finally, the results of the individual and occupational criteria coefficients are used separately as the criteria coefficients in the TOPSIS method to calculate the individual final score, so that after obtaining the individual and occupational criteria coefficients as well as the Individual scores per unit for each criterion consist of the Individual-Individual and Job-Individual criteria decision matrices. Of course, this feature is easily customizable in the system as well as easily weighted average Custom designed system that uses a weighted average of the users.

\section{System implementation and implementation:}

The manager of the department gave the aristocracy of his or her supervised occupations can provide appropriate coefficients for those occupations. Prior to calculate the coefficients of the individual and occupational criteria, each individual and occupation's privileges are first given to him / her by the direct manager. Prior to calculate the individual and occupational criteria coefficients, each of the individual scores during the evaluation period (up to 5 points) on each individual and occupational criterion is obtained from his / her direct manager through the form below. In order to obtain the scores of each employee on the individual and job criteria of unit managers, a form is designed in the system as shown below. 
Table (2): The Form designed in DSS (Decision Support System) for scoring

\begin{tabular}{|c|c|c|c|c|}
\hline \multicolumn{2}{|c|}{ Year of Establishment: } & \multicolumn{2}{|l|}{ N. of employees: } & $\begin{array}{l}\text { N. of } \\
\text { employees: }\end{array}$ \\
\hline \multicolumn{5}{|c|}{ Calculation of individual coefficients } \\
\hline \multicolumn{2}{|c|}{ Individual criteria } & \multicolumn{3}{|c|}{ Occupational Criteria } \\
\hline \multirow{5}{*}{ Social } & Working conscience & \multirow[b]{2}{*}{ Skill } & Education & \\
\hline & $\begin{array}{l}\text { Courtesy of the } \\
\text { employee }\end{array}$ & & Experience & \\
\hline & $\begin{array}{c}\text { Employee } \\
\text { commitment and } \\
\text { responsibility }\end{array}$ & \multirow{6}{*}{ Responsibility } & Supervision & \\
\hline & Discipline & & The safety of others & \\
\hline & Confidence & & Materials and products & \\
\hline \multirow{5}{*}{ Technical } & Pursuit of affairs & & Connecting with others & \\
\hline & $\begin{array}{c}\text { Perseverance and } \\
\text { seriousness at work }\end{array}$ & & Finance & \\
\hline & Work experience & & Forms and reports & \\
\hline & $\begin{array}{l}\text { Mastery of work and } \\
\text { subject knowledge }\end{array}$ & \multirow[t]{2}{*}{ Efforts } & Physical effort & \\
\hline & Productivity & & Mental effort & \\
\hline \multirow{5}{*}{ Managerial } & Focus on goals & \multirow{5}{*}{$\begin{array}{l}\text { Working } \\
\text { condition }\end{array}$} & \multirow{5}{*}{$\begin{array}{l}\text { Unfavorable work } \\
\text { environment / } \\
\text { occupational hazards } \\
\text { and illness }\end{array}$} & \\
\hline & Ability to plan & & & \\
\hline & Communication & & & \\
\hline & Innovation & & & \\
\hline & Creativity & & & \\
\hline
\end{tabular}

The results of the scores given to 6 employees in the organization on individual criteria are as follows. 
Table (3): Results obtained from ratings given to employees of the organization on individual criteria

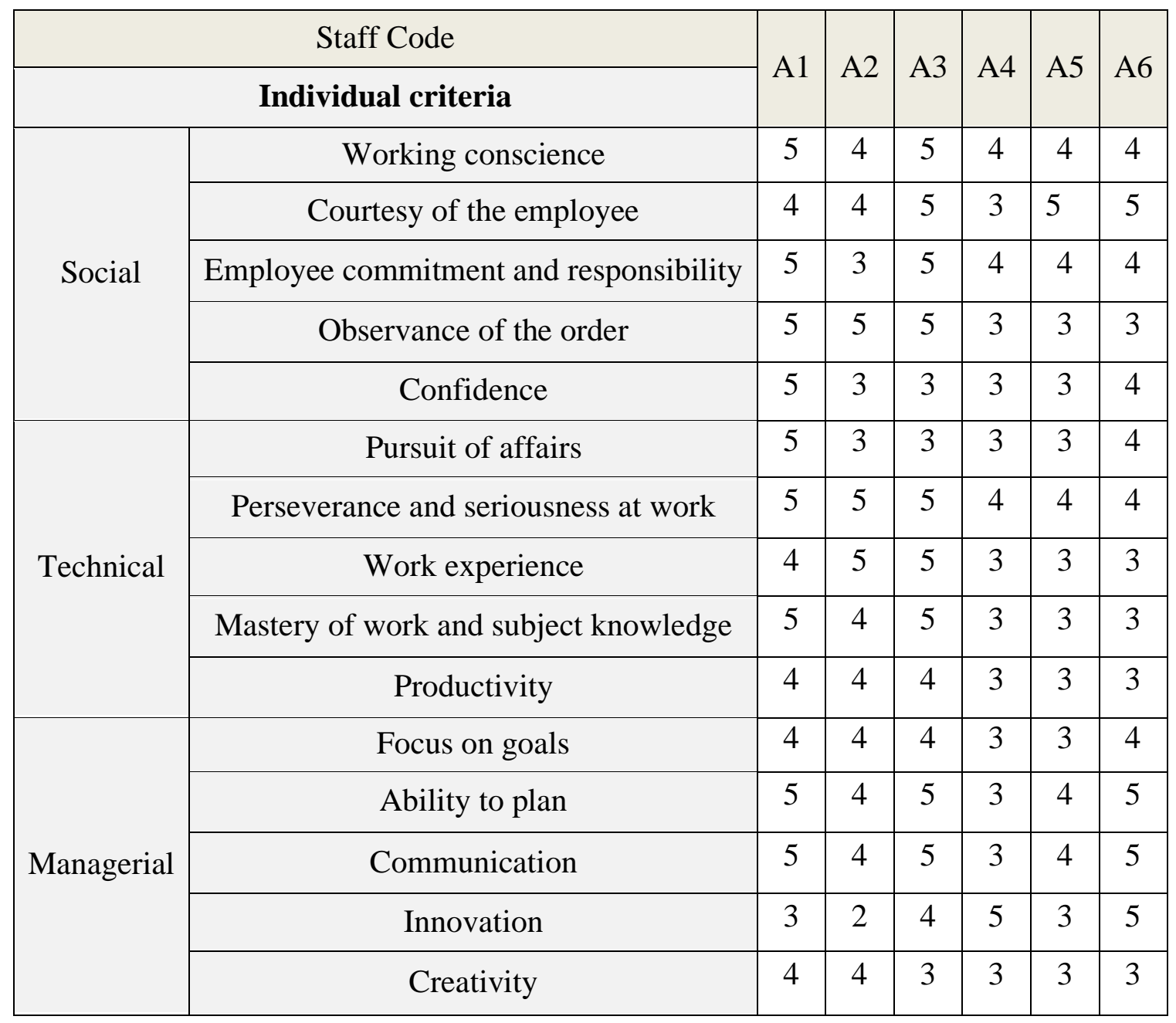

Based on the explanations given in Section 3, for each employee, the individual and occupational criteria are compared through paired comparisons. Formally, according to Table 1, for each employee according to the occupation in which they are employed Paired comparisons (after entering the necessary information by the head of the circle, the head of the department and the head of the individual) are provided by the system. Those are the same points a person gained from those criteria. Here is an example of the results for someone with A1 code that Table (4) presents the scores given to him on individual criteria. 
Table (4): Results from individual and occupational criteria coefficients on code A1

\begin{tabular}{|c|c|c|c|c|c|c|c|c|c|c|c|c|c|c|c|c|}
\hline \multirow{4}{*}{$\begin{array}{c}\text { C } \\
\text { oe } \\
\text { ffi } \\
\text { cie } \\
\text { nt } \\
\text { s } \\
\text { of } \\
\text { cri } \\
\text { te } \\
\text { ri } \\
\text { a }\end{array}$} & \multirow{4}{*}{$\begin{array}{l}\text { in } \\
\text { di } \\
\text { vi } \\
\text { d } \\
\text { u } \\
\text { al }\end{array}$} & \multicolumn{5}{|c|}{ Social } & \multicolumn{5}{|c|}{ Technical } & \multicolumn{5}{|c|}{ Managerial } \\
\hline & & \multicolumn{5}{|c|}{0.049} & \multicolumn{5}{|c|}{0.031} & \multicolumn{5}{|c|}{0.2} \\
\hline & & $\begin{array}{c}\text { W } \\
\text { or } \\
\text { ki } \\
\mathrm{n} \\
\mathrm{g} \\
\mathrm{c} \\
\mathrm{o} \\
\mathrm{ns} \\
\mathrm{ci} \\
\mathrm{e} \\
\mathrm{n} \\
\mathrm{ce}\end{array}$ & $\begin{array}{c}\mathrm{C} \\
\mathrm{o} \\
\mathrm{ur} \\
\text { te } \\
\mathrm{sy} \\
\text { of } \\
\text { th } \\
\mathrm{e} \\
\mathrm{e} \\
\mathrm{m} \\
\mathrm{pl} \\
\mathrm{o} \\
\mathrm{ye} \\
\mathrm{e}\end{array}$ & $\begin{array}{c}\mathrm{E} \\
\mathrm{mp} \\
\text { loy } \\
\text { ee } \\
\text { co } \\
\mathrm{m} \\
\mathrm{mi} \\
\mathrm{tm} \\
\text { ent } \\
\text { an } \\
\mathrm{d} \\
\text { res } \\
\text { po } \\
\text { nsi } \\
\text { bil } \\
\text { ity }\end{array}$ & $\begin{array}{c}\text { O } \\
\text { bs } \\
\text { er } \\
\text { va } \\
\text { nc } \\
\text { e } \\
\text { of } \\
\text { th } \\
\text { e } \\
\text { or } \\
\text { de } \\
\text { r }\end{array}$ & $\begin{array}{c}\mathrm{C} \\
\text { on } \\
\mathrm{fi} \\
\mathrm{de} \\
\mathrm{nc} \\
\mathrm{e}\end{array}$ & $\begin{array}{l}\mathrm{P} \\
\text { ur } \\
\text { su } \\
\text { it } \\
\text { of } \\
\text { af } \\
\text { fa } \\
\text { irs }\end{array}$ & $\begin{array}{c}\text { Pe } \\
\text { rse } \\
\text { ve } \\
\text { ra } \\
\text { nc } \\
\text { e } \\
\text { an } \\
\text { d } \\
\text { ser } \\
\text { io } \\
\text { us } \\
\text { ne } \\
\text { ss } \\
\text { at } \\
\text { wo } \\
\text { rk }\end{array}$ & $\begin{array}{c}\mathrm{W} \\
\text { or } \\
\mathrm{k} \\
\mathrm{e} \\
\mathrm{x} \\
\mathrm{p} \\
\mathrm{er} \\
\mathrm{ie} \\
\mathrm{n} \\
\mathrm{ce}\end{array}$ & $\begin{array}{c}\mathrm{M} \\
\text { as } \\
\text { te } \\
\text { ry } \\
\text { of } \\
\mathrm{w} \\
\text { or } \\
\mathrm{k} \\
\mathrm{a} \\
\mathrm{n} \\
\mathrm{d} \\
\mathrm{su} \\
\mathrm{bj} \\
\mathrm{ec} \\
\mathrm{t} \\
\mathrm{k} \\
\mathrm{n} \\
\mathrm{o} \\
\mathrm{w} \\
\mathrm{le} \\
\mathrm{d} \\
\mathrm{g} \\
\mathrm{e}\end{array}$ & $\begin{array}{l}\text { Pr } \\
\text { od } \\
\text { uc } \\
\text { tiv } \\
\text { ity }\end{array}$ & $\begin{array}{l}\mathrm{F} \\
\mathrm{o} \\
\mathrm{c} \\
\mathrm{u} \\
\mathrm{s} \\
\mathrm{o} \\
\mathrm{n} \\
\mathrm{g} \\
\mathrm{o} \\
\mathrm{a} \\
1 \\
\mathrm{~s}\end{array}$ & $\begin{array}{l}\text { A } \\
\mathrm{b} \\
\mathrm{i} \\
\mathrm{l} \\
\mathrm{i} \\
\mathrm{t} \\
\mathrm{y} \\
\mathrm{t} \\
\mathrm{o} \\
\mathrm{p} \\
\mathrm{l} \\
\mathrm{a} \\
\mathrm{n}\end{array}$ & $\begin{array}{l}\text { Co } \\
\text { mm } \\
\text { uni } \\
\text { cati } \\
\text { on }\end{array}$ & $\begin{array}{c}\text { In } \\
\mathrm{n} \\
\mathrm{o} \\
\mathrm{v} \\
\text { at } \\
\text { io } \\
\mathrm{n}\end{array}$ & $\begin{array}{l}\text { C } \\
\text { re } \\
\text { at } \\
\text { iv } \\
\text { it } \\
\text { y }\end{array}$ \\
\hline & & $\begin{array}{c}0.08 \\
28\end{array}$ & $\begin{array}{c}0.12 \\
38\end{array}$ & $\begin{array}{c}0.088 \\
0\end{array}$ & $\begin{array}{c}0.09 \\
47\end{array}$ & $\begin{array}{c}0.10 \\
69\end{array}$ & $\begin{array}{c}0.03 \\
44\end{array}$ & $\begin{array}{c}0.08 \\
49\end{array}$ & $\begin{array}{c}0.06 \\
50\end{array}$ & $\begin{array}{c}0.05 \\
64\end{array}$ & $\begin{array}{c}0.05 \\
97\end{array}$ & $\begin{array}{l}0 . \\
02 \\
22\end{array}$ & $\begin{array}{c}0.0 \\
23 \\
1\end{array}$ & $\begin{array}{c}0.042 \\
6\end{array}$ & $\begin{array}{c}0.02 \\
36\end{array}$ & $\begin{array}{c}0.0 \\
272\end{array}$ \\
\hline
\end{tabular}




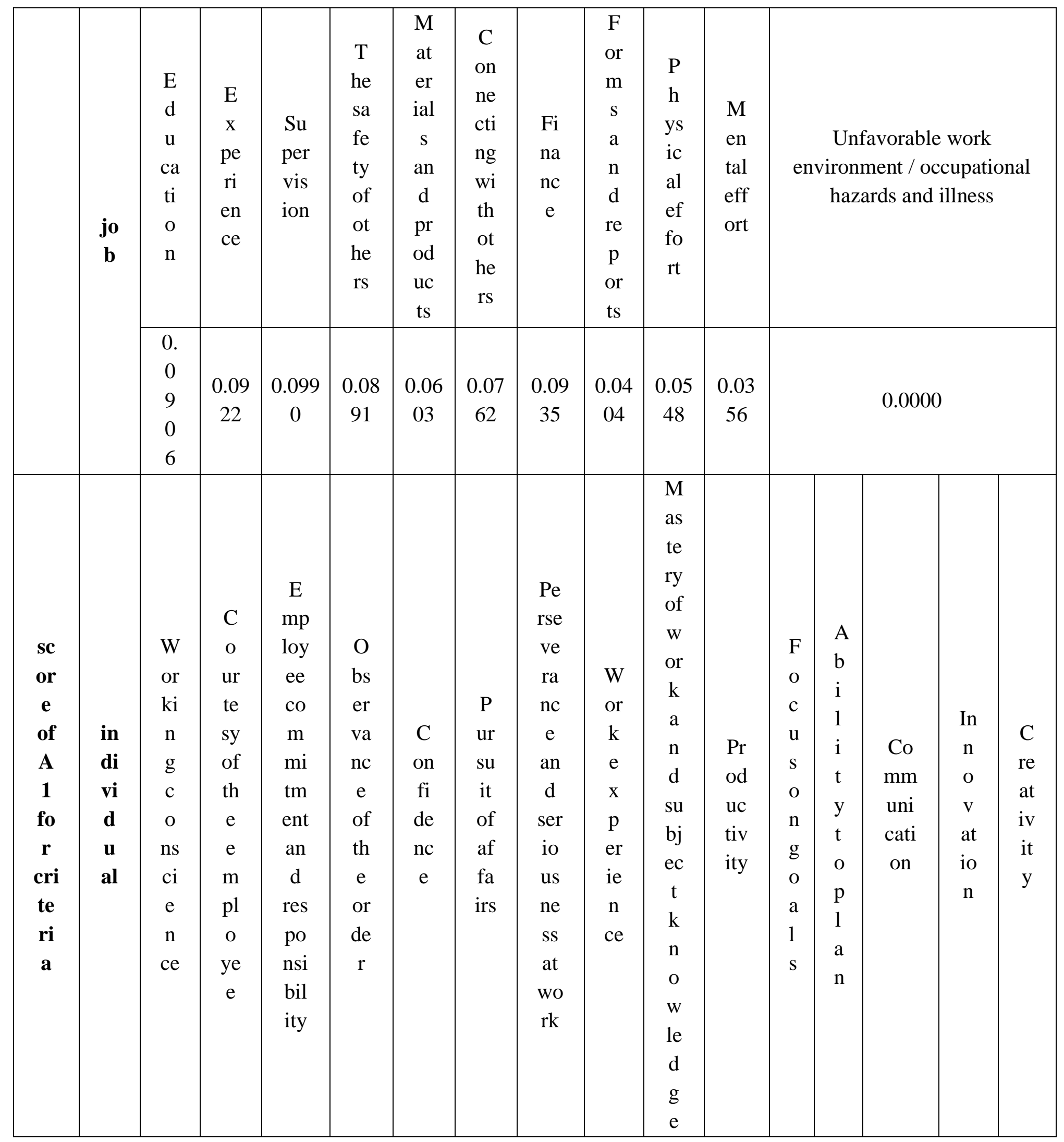




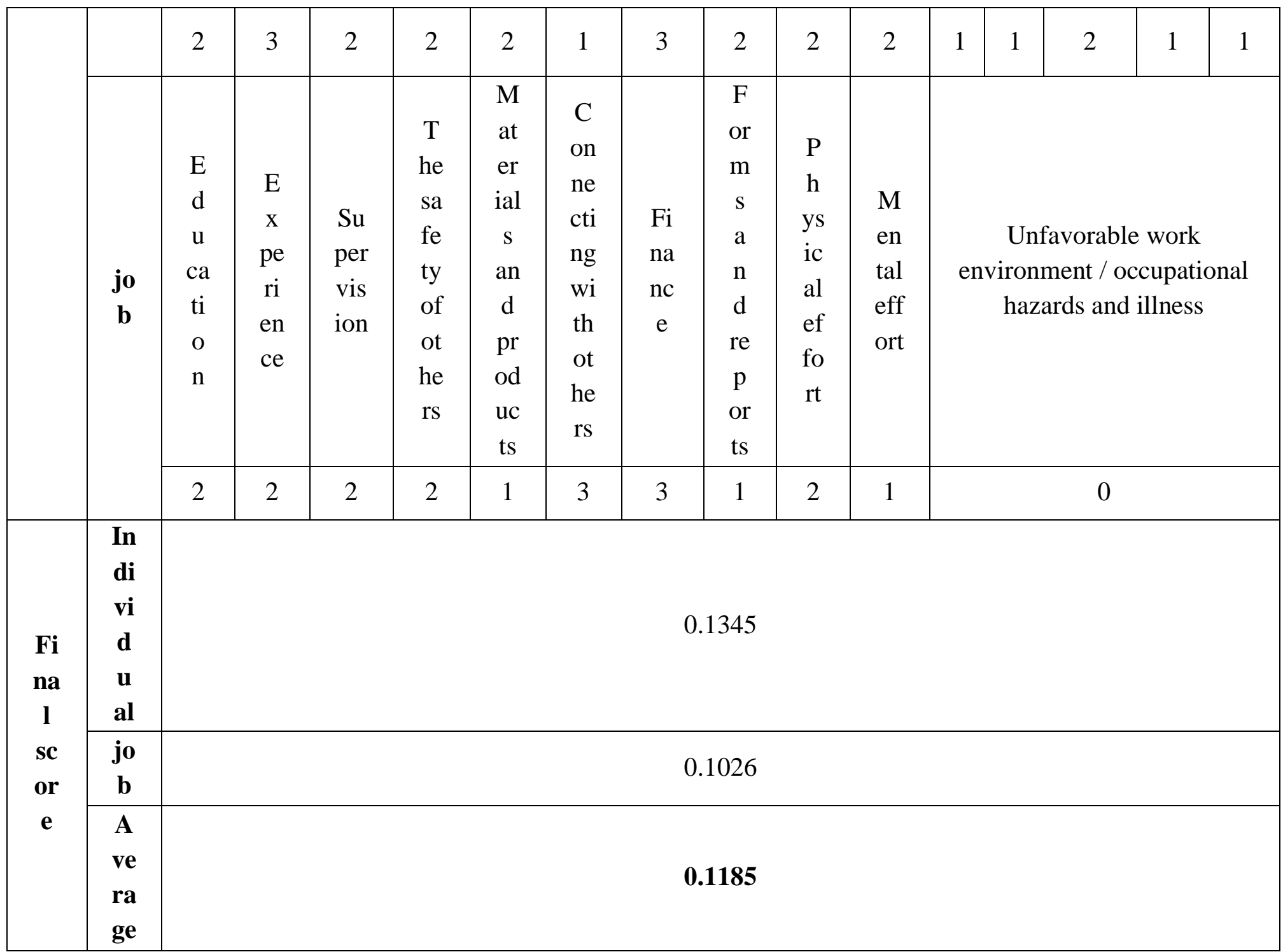

The final result of the scores of employees employed in the organization after applying the TOPSIS algorithm is presented in two separate sections on job criteria and individual criteria in accordance with Table (5). 
Table (5): Organization Staff Ranking

\begin{tabular}{|c|c|c|c|c|c|}
\hline $\begin{array}{l}\text { Staff } \\
\text { Code }\end{array}$ & Department & $\begin{array}{l}\text { Score of employee for } \\
\text { individual criteria }\end{array}$ & $\begin{array}{c}\text { Score of employee for } \\
\text { job criteria }\end{array}$ & Average & Rank \\
\hline A1 & Government Sector & 0.1345 & 0.1026 & 0.1185 & 10 \\
\hline A2 & Provide & 0.2387 & 0.3140 & 0.2763 & 8 \\
\hline A3 & $\begin{array}{c}\text { Individual Current } \\
\text { Account }\end{array}$ & 0.6593 & 0.6358 & 0.6476 & 3 \\
\hline A4 & Accounting & 0.5090 & 0.5640 & 0.5365 & 4 \\
\hline A5 & Internal transfers & 0.3932 & 0.5073 & 0.4503 & 6 \\
\hline A6 & Banking facilities & 0.1998 & 0.1920 & 0.1959 & 9 \\
\hline A7 & Administration & 0.3207 & 0.3534 & 0.3370 & 7 \\
\hline A8 & Treasurers & 0.7440 & 0.7115 & 0.7277 & 2 \\
\hline A9 & IT & 0.8536 & 0.9196 & 0.8866 & 1 \\
\hline A10 & Retirement & 0.4642 & 0.5759 & 0.5201 & 5 \\
\hline
\end{tabular}

\section{Conclusion and Suggestions:}

In this study, while trying to evaluate different methods of employee performance evaluation in organizations, it is proposed to present a model in the form of a decision support system in order to evaluate the performance of employees in the organization. In order to see how the model is implemented, an example is provided, in which the staff of the organization is evaluated and rated using this system.

In order to execute the model more accurately, it is recommended that a person or group be consulted on all the jobs of the organization to comment on all the coefficients of the available jobs in the organization to make assertions about the business coefficients that underlie the proposed model. Also add a 360-degree evaluation method to measure people from different perspectives. 


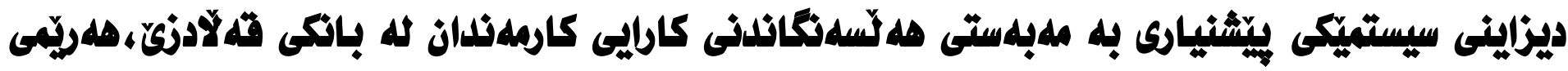 كوردستانى ميراق}

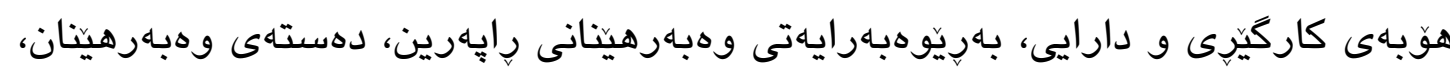
موزثًان ئيبراهيم حسن هلهوليّر، هـاريمى كوردستان، عيّراق. ئيمهيل: ebrahim.mozhgan@gmail.com

بهشى بازركانى كاركيّرى كار، كؤليّزّى بازركانى و ئابورى، زانكوى لوبنانى فهرهنسى، ئاسو كوردوّ احمد هداوليّر، هـاريّمى كوردستان، عيّراق. ئيمهيل: Aso.Ahmed@lfu.edu.krd

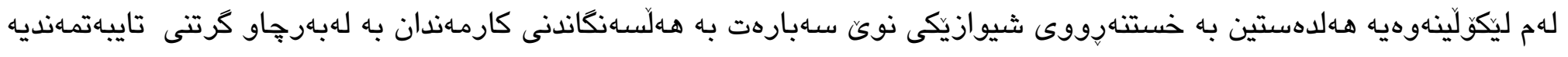

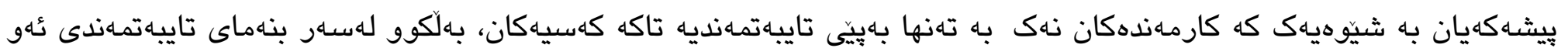

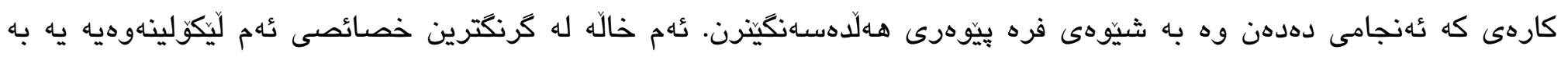

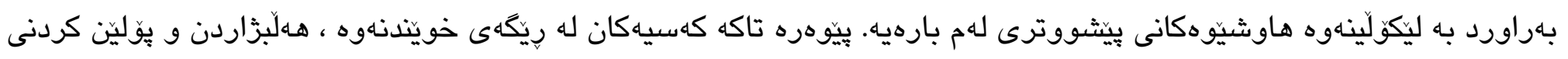

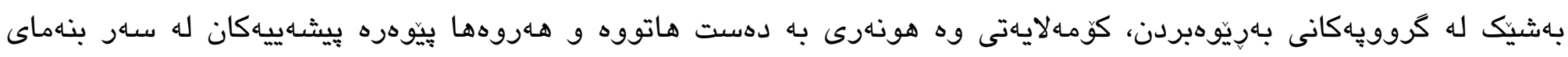

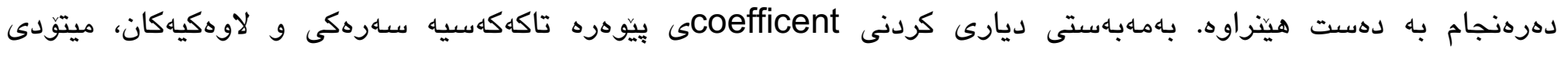

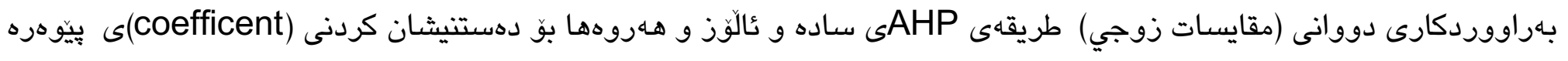

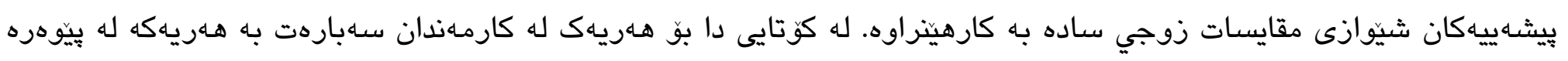

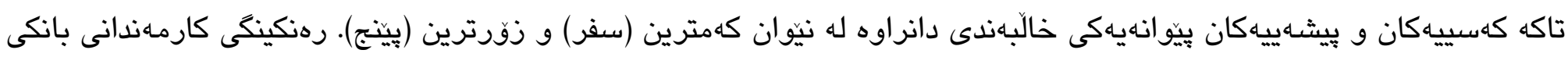

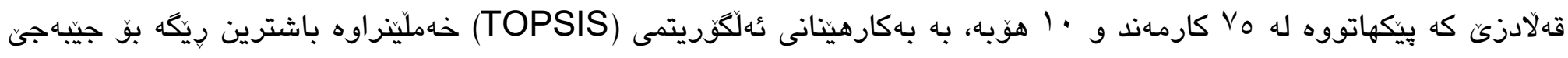

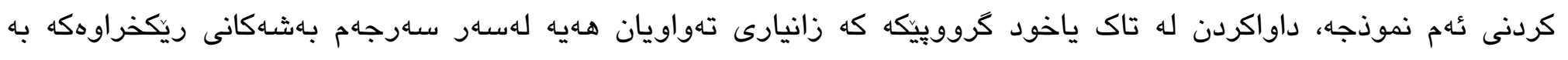

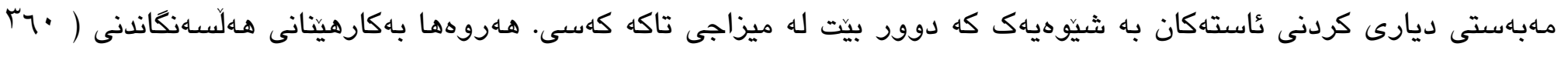

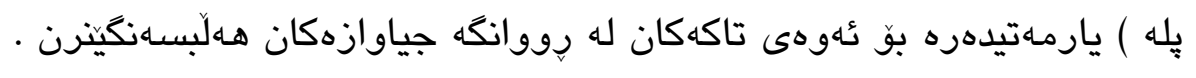

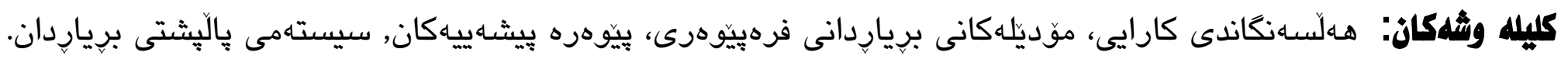




\section{References:}

Asgharpour, Mohammad Javad (2008), Multi-Criteria Decision Making, Institute of Publishing and Printing, University of Tehran, sixth edition.

C. Moon, J. Lee, C. Jeong, J. Lee, S.Park and S. Lim (2007), "An implementation case for the performance appraisal \& promotion ranking", IEEE, 661-667.

C. Moon, J. Lee, S. Lim (2010), "A performance appraisal and promotion ranking system based on fuzzy logic: An implementation case in military organizations", Applied Soft Computing, 10(2), 512-519.

Jalaian zafarani, zahra. seifbarqi, mahdi, (2013), IT management studies, designing a decision support system to evaluate employee performance; Case Study in Export Development Bank of Iran, First Year, Third Issue, Pages 1-17.

Karimi Dastjerdi, Davood, (Spring 2007), Performance Evaluation of Gas Transmission Operation Areas Based on Performance Charter, Third National Conference on Performance Management.

M. Espinilla, R. de Andrés, F.J. Martínez, L. Martínez, (2013)"A 360-degree performance appraisal model dealing with heterogeneous information and dependent criteria", Information Sciences, 222, 459-471.

Saadat, Esfandiar, (Summer 2007), Human Resource Management, Samat Publications, 13th Edition.

Ronagh, Yousef, (2007), Plan for classification and evaluation of jobs of employees of executive bodies, subject to the law of coordinated payment system in Iran, Institute for Development and Improvement of Management, Farmanesh Publications, First Edition.

P.D.D.Dominic, I. Abdul Aziz, K.N. Goh (2008), "A decision support system for performance appraisal", IEEE computer society, 899-903.

Y-J. Wu, J-L. Hou (2010), "An employee performance estimation model for the logistics industry", Decision Support Systems, 48(4), 568-581. 